\title{
ON GOOD AUTHORITY: ANNA FREUD AND THE POLITICS OF CHILD ANALYSIS
}

\author{
Carolyn Laubender, Durham NC, USA
}

The technique of child analysis, insofar as it is special at all, derives from one very simple fact: that the adult is - at least to a considerable degree - a mature and independent being, while the child is immature and dependent. It is evident that to deal with such different subjects the method cannot remain the same.

Anna Freud, 1926, p. 5

\section{CAROLYN LAUBENDER ...}

In the foreword to a 1925 text on juvenile delinquency by August Aichhorn titled Wayward Youth, Sigmund Freud introduces the importance of Aichhorn's work by hailing 'the child' as the future of psychoanalysis. As Freud writes,

Of all the fields in which psychoanalysis has been applied none has aroused so much interest, inspired so much hope, and accordingly attracted so many capable workers as the theory and practice of child training. ... The child has become the main object of psychoanalysis research and in this respect has replaced the neurotic(Freud, 1925, p. v)

Noting the interest in and wide appeal of the 'application' of psychoanalysis to pedagogy, Freud concludes that the child has in fact become the 'main object of psychoanalysis' itself, effectively displacing - or replacing - the neurotic. In this foreword, Freud famously refers to psychoanalysis as a 're-education,' or translated more accurately an 'after-education,' suggesting that an adult analysis is the necessary supplement to the child's primary schooling (Freud, 1925, p. vii). ${ }^{1}$ While these prefatory remarks are intended as a commentary on Aichhorn's work with 'wayward youth,' Freud's observation about the growing importance of the child for psychoanalysis writ large registers his more general recognition of the emerging body of work

\footnotetext{
${ }^{1}$ The original German term, Nacherziehung, is first translated throughout Sigmund Freud's work as 'reeducation'; however, the editors of the Standard Edition note that this is a substantial mistranslation since 'nach' conveys a temporal element, an 'after'-ness, rather than a repetition.
} 
produced by socially-minded psychoanalytic reformers, such as Anna Freud, Siegfried Bernfeld, Willi Hoffer, and Hermine Hug-Hellmuth, all of whom put the child at the center of their psychoanalytic agendas. If the child had become the main object of psychoanalytic inquiry, then it seems hardly incidental that one of the most famous child psychoanalysts was in fact Freud's own child, Anna Freud, who was born the same year as psychoanalysis and, from the first, counted herself as its sibling, its 'twin.'

This article analyzes the political stakes of the child psychoanalysis that Sigmund Freud heralded by reading Anna Freud's clinical papers on child analytic technique. If the child was to be the future of an international institution, profession, and practice, then how exactly was this future tied to and delimited by the political landscape of the time? Insofar as the question of authority becomes a keynote concern for Anna Freud in her theories about children's subjectivity, to what extent are these theories consolidating explicitly political concerns about power, authority, and governance in interwar Europe? In other words, how might Anna Freud's early clinical technique with children speak not only to the uncertain future of psychoanalysis, but also to larger national anxieties about the decline of monarchial empire and the rise of multiple national democracies and republics, including the Republik Österreich, the First Austrian Republic?

To address these questions, I begin by situating Anna Freud and her early work within the social and intellectual climate of interwar Vienna. Anna Freud's interest in education and children put her in conversation with a number of social and political reformers and radicals and it was in the context of these explicitly politicized mobilizations of psychoanalysis that Anna Freud's first iterations of child psychoanalysis were conceived. As I discuss, Anna Freud's adaptation of psychoanalysis for children was founded on a developmental theory of childhood, 
one that hinges on her postulation that the child's superego is undeveloped and therefore objectdependent. Anna Freud's clinical technique reflected this surmise about the child's fundamental dependence in the way her technique stressed the importance of authority; Anna Freud redefined the analyst's function as both analytic and pedagogical. Focusing on the importance Anna Freud accorded to authority in the clinic, I contend that this interwar consideration of the legitimate and justifiable place of authority in the clinic participates in a broader historical conversation about the uncertain function of authority in democratic politics. Far from being removed from the socio-political order, Anna Freud's clinical writings affirm that the psychoanalytic clinic is always already in conversation with the historical context in which it is embedded.

\section{Psycho-Politics: Child Analysis and Social Reform}

By the time Wayward Youth was published in 1925, Anna Freud had already been qualified as a psychoanalyst in the Vienna Psychoanalytic Society for three years and was hard at work developing a specific psychoanalytic technique for the analysis of children, an approach she would describe in detail a year later in An Introduction to the Technique of Child Analysis (1926). Although she had first trained as a teacher, Anna Freud's professional trajectory eventually returned her to her psychoanalytic twin and, along with Melanie Klein and Hermine Hug-Hellmuth, she became one of the first practicing child psychoanalysts. ${ }^{2}$ Not insignificantly, 1925 was also the same year that child analyst Melanie Klein gave a weeklong series of lectures on child psychoanalysis to the British Psychoanalytic Society at the request of the society's

\footnotetext{
${ }^{2}$ Hug-Hellmuth was the first child psychoanalyst and her pedagogical aspirations were not dissimilar to Anna Freud's. However, Hug-Hellmuth's early death (she was murdered by her nephew in 1924) meant that most of her papers were destroyed per the specifications of her will. Consequently, much less has been written about her than has been about Anna Freud and Melanie Klein. For further reading see: 'Introduction' and 'The Origins of Child Analysis' in Holder (2005); and Geissmann and Geissmann (1998). You can't make note-bubbles in footnotes, but is there a reason to keep some chapter specifications for texts but not others (i.e. the ref to Holder, but not to Geissmann and Geissmann)?
} 
president, Ernest Jones. Thus, child analysis was already an active subspecialty the year Sigmund

Freud wrote his forward to Aichhorn's work and it was being pioneered, importantly, by a coterie of rising women analysts who contributed to a growing interest in the analysis of female sexuality, maternity, and childhood. Woman-focused child analysis would only gain in popularity and importance in the decades to come (especially in England), a fact clearly evidenced when, in the years immediately after Freud's death, the entire institutional future of psychoanalysis in Britain hinged on the heated debates between Anna Freud and Melanie Klein. ${ }^{3}$ While not active in political movements per se, Anna Freud's work with children put her in collaboration with many political liberals, leftists, and social(ist) reformers. ${ }^{4}$ In Vienna after World War I, progressives (both liberal and Marxist alike) increasingly turned their attention to the prophylactic protection of children through the liberalization of prior educational repression and lobbied for the reorganization of many social institutions, including primary schools, churches, prisons, universities, government regulations, sexual mores, and gender conventions. Many of these reformers, like Maria Montessori (whom Anna Freud greatly admired), looked to children's education as an exemplary site where the liberalization of oppressive strictures could facilitate large-scale political transformations and they often incorporated psychoanalytic

\footnotetext{
${ }^{3}$ Although in many ways the professional conflict between Anna Freud and Melanie Klein culminated in the so-called 'Controversial Discussions' (1941-46) held by the British Psychoanalytical Society (BPaS), their disagreements with one another spanned decades. As early as 1927, Klein and other notable British analysts were already leveling substantial (and often vitriolic) critiques at Anna Freud's first book at a symposium organized by Ernest Jones. Anna Freud responded with biting dismissals of her own, and the differences between their interpretations of Freudian theory eventually resulted in an ironically named 'gentleman's agreement' between the two women that split the BPaS definitively into two different professional trainings (plus a 'middle' or 'independent' group that worked between the two). While they were collegial professionally, they never arrived at anything like theoretical or personal resolution and the fundamental differences between their approaches still shape psychoanalytic institutes today. For further reading on this conflict, see King and Steiner (1991). For an excellent social analysis, see Rose (1993) and Phillips's response (Phillips, 2001). Britzman (2003) also has an excellent analysis of the central role that education played in these debates.

${ }^{4}$ For information about Anna Freud's political affiliations, see Young-Bruehl, 2008, 177-78.
} 
insights into their social and political agendas. Reflecting retrospectively on the historical development of child psychoanalysis, Anna Freud commented in an interview in 1970 on the importance of this interwar political situation for the advent of child analysis:

There is no doubt that child analysis began as a subspecialty of psychoanalysis, in the period after the First World War when several such subspecialties were initiated. What was later known under the slogan of the 'widening scope of psychoanalysis' were the attempts made from the 1920s onward to apply the therapeutic technique devised for adult neurotics to other ages or to other types of mental disorder. (A. Freud, 1970, p. 209)

In response to the new kinds of trauma experienced by returning soldiers, and no doubt also to the dramatic political reorganization of Europe that followed the close of World War I, interbellum psychoanalysis modified and adapted its clinical techniques and theoretical insights to address the needs of not just individuals but mass populations. ' ${ }^{5}$ Our dream was the dream of psychoanalysis - all it had to offer,' reflects Anna Freud, 'not only individuals, but schools and universities and hospitals and the courts and "reform schools" that worked with "delinquents", and social service agencies' (in Coles, 1992, p. 152). Anna Freud counted child analyses amongst these many interwar subspecialties, thinking of it as one of many attempts to expand psychoanalysis's purview beyond the limited scope of neurosis.

Many of these offshoots of psychoanalysis - including child analysis - were more than just a simple 'application' of psychoanalysis, however. Indeed, they often radically transformed the nature of previous psychoanalytic knowledge on which they were based, explicitly extending and modifying psychoanalytic orthodoxy in accordance with specific social and political ideals. 1920s Vienna witnessed a flowering of such psychoanalytically informed reformers: while August Aichhorn tried to liberalize juvenile delinquency homes, Wilhelm Reich sought to undo the pernicious effects of repressive hetero-patriarchal capitalism with mobile clinics, free

\footnotetext{
${ }^{5}$ For an interesting study of one specific instance of this, see Danto (2005).
} 
contraceptives, and different forms of touch therapy. Although the 'psychologization' of politics had been a popular mode of political theorizing since the late nineteenth century - consider, for example, Gabriel Tarde's Les Lois de l'Imitation (1890) or Gustave Le Bon's Psychologie des Foules (1895) - the advent of psychoanalysis and publication of some of Sigmund Freud's more explicitly political work during the interwar period (Group Psychology and the Analysis of the Ego (1921); Civilizations and Its Discontents (1930)) only strengthened a widespread understanding of socio-political life as thoroughly bound up with personal psychologies. As Eli Zaretsky confirms in his social and cultural history of psychoanalysis, Secrets of the Soul:

In contrast to those that had propounded the classical liberal separation of public and private life, the thinkers of the 1930s recognized the unavoidably psychological and cultural character of modern politics, and thus the impossibility of separating the problems of democracy from those of personal autonomy, gender and sexuality, group identity, and the commodification of everyday life. (Zaretsky, 2004, p. 244)

Unsurprisingly, this was the context that produced the first iterations of The Frankfurt School, whose members (like Theodor Adorno, Erich Fromm, and Herbert Marcuse) generated powerful critiques of capitalism, authoritarianism, and (hetero)normative bourgeois family life. This style of psychoanalytically informed political theorizing gained traction in the decades following World War II especially, but its origins lie in the same historical mise-en-scene as those of child analysis.

No less than her male colleagues, then, Anna Freud pursued a definitively political project when she began her psychoanalytically informed work with children. Together with social reformers Willi Hoffer, August Aichhorn and Siegfried Bernfeld, Anna Freud formed a weekly study group in the 1920s to discuss the relationship between psychoanalysis and pedagogy. In Reading Anna Freud, Nick Midgley observes that this express focus on education was part of a larger political movement to use psychoanalytic insights to illuminate not just 
subjectivity, but more specifically the child's subjectivity. Children were a cynosure for many social and political reformers in the left-leaning 'Red Vienna.' As Midgley writes:

The radical reforms of education - understood as one aspect of a wider child welfare program - meant that many of the most idealistic and enthusiastic young people in Vienna chose to train as teachers. A significant proportion of these same young idealists were naturally attracted to psychoanalysis and wished to bring together their interest in educational reform with their enthusiasm for this new 'science of the mind,' which promised to revolutionize the way people thought about the psychology of the child. (Midgley, 2013, p. 35)

What Midgley suggests here is that an interest in children's education was also an interest in the explicitly political potential of the child's mind. If, according to these reformers, individual psychology determined much of the shape of social and political organizations and institutions, then the careful curation of childhood experiences held the promise of transforming the political attachments that solidified in adulthood. Attending to the wellbeing of the child was the first step in engineering a specific political future.

This political bent to Anna Freud's work with children has most often been recognized in her expansive postwar institutional work with children. ${ }^{6}$ But, as I argue here, Anna Freud's clinical, as much as her social, work participates in this political discourse about governmentality and democracy, albeit in more obviously ambivalent ways. In what follows, I analyze Anna Freud's interwar clinical writings, which I argue advance an ethics of authority that complicates the nature of the democratic implications of her work. If, as Stewart-Steinberg has argued, Anna Freud's postwar institutional work with children in group homes testifies to her experimental production of horizontal, democratic power relations, then her interwar clinical technique reveals a different theory of democracy by attesting to a belief in the indispensability of hierarchical authority, especially as represented by the superego. Throughout these interwar

\footnotetext{
${ }^{6}$ For examples of this kind of scholarship, see Shapira (2013) and Stewart-Steinberg (2011).
} 
writings, Anna Freud frets about the necessity of authority in the clinic, ultimately resolving that the child legitimately requires authoritative guidance since the dismantling of authority would only ever result in the loosing of murderous and sexual instincts, instincts that are antithetical to the reproduction of a stable and non-violent civil society. Contra socialist liberationist theorists like Wilhelm Reich or Herbert Marcuse who narrated the genesis of social malaise as a result of unnecessary repressions by the superego (classically represented by the patriarchal Oedipal father), Anna Freud instead focused her clinical energies on the cultivation of precisely this psychic 'institution,' imagining the child to be developmentally 'immature' and 'dependent' and therefore in need of external (analytic) authority. ${ }^{7}$

By homing in on the way Anna Freud's early work theorizes the child and clinical technique, my aim is thus not to dismiss her clinical work as somehow an 'inauthentic' or 'failed' version of psychoanalysis, but rather to expand the reach of historical and political readings of psychoanalysis by proposing that clinical methods, as much as public outreach, are enabled by and experimentally speak back to available political vocabularies. With a unique emphasis on authority, Anna Freud's interwar work in the clinic participated in a broader political speculation about the shortcomings of democracy and the extent to which a consolidating authority was democracy's necessary supplement.

\footnotetext{
${ }^{7}$ Whereas Sigmund Freud had referred to the three entities in his second topography - the id, the ego, and the superego - as "agencies" [instanz], Anna Freud interestingly refers to them as 'institutions' throughout her writings, both in English and in German. This is an interesting modification of Freud's original nomenclature since it corresponds to Anna Freud's principally institutional role in psychoanalysis: not only did she herself run a number of children's institutes, but after Sigmund Freud's death she was also responsible for much of the institutionalization of psychoanalysis itself, both in Britain and in the United States.
} 


\section{The Developing Child: Anna Freud, the Child, and the Superego}

Although the first generation of child psychoanalysts worked and taught in roughly the same historical contexts and geographical locations - pre-World War II Vienna to wartime and postwar London - their theories of the child were often worlds apart. ${ }^{8}$ Each individual analyst developed highly particular theories about what kind of being 'the child' was and, consequently, each crafted unique clinical techniques tailored to the specificity of the child-mind, as they variously understood it. Anna Freud, for instance, advanced a generally developmental understanding of subjectivity that focused on the ego and the superego as the metric for childhood development. The child was essentially an 'incomplete' version of the adult subject since, in her view, children lacked stable egos and solidified superegos, both of which were precipitated by the successful resolution of the Oedipus complex. Because Anna Freud was utilizing the developmental stages inherent in the Oedipus complex, the chronological age of a child was of great importance to her theories of psychic life. Categories like 'infant,' 'child,' 'adolescent,' and 'adult' were meaningful ways of marking psychic difference. She maintained that infants are primarily auto-erotic with little interest in or awareness of the specificity of the objects in their world so long as their instincts are satisfied. According to this model, as the child ages it slowly begins to incorporate its external world through a process of identification, building its ego and superego from the composite images of the authorities around it. Anna Freud affirms this in 'Child Analysis and the Upbringing of Children' (1926), an early essay from her book on clinical technique, in which she defines the child vis-à-vis the more 'developed' adult:

\footnotetext{
${ }^{8}$ For general histories of 'the child' and childhood, see Aries (1965) much contested history of childhood or the more recent Cunningham (1995). For more specific and local analyses, see Hendrick (1997); Shuttleworth (2010); Steedman (1995); and Castañeda (2002). For a psychoanalytically-focused comparative analysis of the different versions of childhood presented by Anna Freud and Melanie Klein, respective to Western modernity, see Bar-Haim (forthcoming, 2017).
} 
[T] he superego of an adult individual has become the representative of the moral demands made by the society in which he lives... what was originally a personal obligation felt toward the parents becomes, in the course of development, an ego ideal that is independent of its prototypes in the external world.

In the case of a child, however, there is as yet no such independence. Detachment from the first love objects still lies in the future, and identification with them is accomplished only gradually and piecemeal. Even though the superego already exists and interacts with the ego at this early period much as it does in later times, its dependence on the objects to which it owes it existence must not be overlooked... (A. Freud, 1926, pp. 54-55, emphasis added)

This passage merits pause because of how it (unexpectedly) cites object-dependence as a hallmark of childhood. Here, Anna Freud purports that children's psyches are different from adults' in key structural ways: they lack an independent, internalized superego, relying instead on the structural authority provided by the outside world (though figures like parents, teachers, and, as I shall discuss, analysts). For Anna Freud, the superego crystalizes developmentally as the child passes through the sequences of the Oedipus complex and slowly internalizes 'authorities' that had previously been only external. Because of this developmental rubric, Anna Freud surmises that the child lacks a consolidated internal authority and is thus fundamentally bound to and dependent upon external authorities.

Of pivotal importance here is the recognition that Anna Freud measures the child's development - its maturity - according to the status of the superego, that internal representative of external authority. Freud continues: 'insofar as the childish superego has not yet become the impersonal representative of the demands taken over from the outer world, and is still organically connected with it - to that extent the relevant external objects play an important role in the analysis itself' (A. Freud, 1926, p. 58). The inchoate nature of the child's superego means that the child itself is dependent on its external objects, objects that (as I will discuss) she explicitly defines as representing 'authority.' 
I am highlighting this language of object-dependency within Anna Freud's work, especially insofar as it relates to the metapsychological genesis of the superego, because it productively disrupts the rote juxtaposition of Anna Freud's 'instinct theory' with Melanie Klein's 'object relations.' In the most reductive characterization of these two positions, Anna Freud's emphasis on the instincts and primary narcissism means that her theory of the child is rather insensible to the primacy of particular objects in the infant's and child's psychic life; in contrast, as the originator of object relations psychoanalysis, Melanie Klein is said to downgrade the biological imperatives of the instincts and privilege instead the originary importance of external objects. Rough though this sketch certainly is, it captures something of how, as a result of the Controversial Discussions in the 1940s, 'the instinct' has been retrospectively counterpoised to 'the object' as representatives of two diametrically opposed schools of thought.

But while this narrative does speak to certain differences of emphasis within their respective oeuvres, it dramatically reduces the complexity of each, foreclosing a recognition of the unusual role that object dependency plays in Anna Freud's work, on the one hand, and the vast swaths of instinctual, biological phylogenesis that enable Melanie Klein's systematic thought, on the other. Although Klein does maintain throughout her life that the child's external environment and object relations matter even in its earliest psychic life, the extent to which she relies on biological theories of instincts and phylogenetically transmitted object representations seriously complicates (and, in fact, diminishes) the role that the external world plays in the psychic drama of Klein's child. For Klein, far more than Anna Freud, the child's primary organizing conflict is between the "life instinct" and the "death instinct." "Klein insists that the

\footnotetext{
${ }^{11}$ Unlike Sigmund Freud who often used 'Trieb' (drive) instead of 'Instinkt' (instinct), Klein relies heavily on the latter term both in German and in English (although almost all of her post-1920s writing is in English).
} 
child's experience of object relations in the external world is always colored by its relations to objects in its internal world, where objects are the psychic representatives of instincts. For Klein, the child comes into the world with an instinctual world of its own; its mind is prepopulated by phantasies that stem from somatic origins and instinctual inheritances. ${ }^{12}$ Klein's account of the child's unconscious phantasy — a concept central to her unique theory of subjectivity — is (d)riven by the body's instincts and their vicissitudes.

\section{'Allowing Her 'Devil' to Speak': Anna Freud and The Analyst's Authority in the Clinic}

Anna Freud's understanding of the developing child as a psychologically immature and therefore externally dependent organism is reflected in her proposition of two significant (and connected) modifications of Sigmund Freud's 'classical' psychoanalytic technique. First, because of the unique circumstances of child analysis, Anna Freud argues that the child analyst needs to cultivate a specifically positive transference in the child patient. Whereas a defining aspect of psychoanalytic technique with adult patients is the transference wherein patients transpose past desires and anxieties, loves and hates, onto the person of the analyst, Anna Freud claims that, because the child is still very much attached to and dependent on the presence of the actual parents themselves, the possibilities for any full-bodied transference are strictly limited. Explaining this in 'The Role of Transference in the Analysis of Children' in Four Lectures on Child Analysis, she observed:

Unlike the adult, the child is not ready to produce a new edition of his love relationships, because, as one might say, the old edition is not yet exhausted. His

\footnotetext{
12 'Even the quite small child,' writes Klein, 'which seemingly knows nothing about birth, has a very distinct unconscious knowledge of the fact that children grow in the mother's womb' (Klein, 1927, p. 173). Endowed with this unconscious, instinctual knowledge, children 'represent symbolically phantasies, wishes and experiences [in their play]. Here they are employing the same phylogenetically acquired mode of expression as we are familiar with from dreams' (Klein, 1926, pg.134).
} 
original objects, the parents, are still real and present as love objects... there is no necessity for the child to put the analyst fully in the parents' place, since compared to them he has not the same advantages which the adult finds when he can exchange his fantasy objects for a real person. (A. Freud, 1926, p. 45)

Children, in other words, are creatures caught in the thrall of their everyday environments.

Because of this, the child analyst must actively court the child's affection. 'I take great pains,' she writes, 'to establish in the child a strong attachment to myself, and to bring him into $a$ relationship of dependence on me... This affectionate attachment, i.e., the positive transference to the analyst, becomes the prerequisite for all later analytic work' (A. Freud 1926, p. 40). These 'great pains,' which the child analyst takes to secure the child's dependence, recall Anna Freud's previous descriptions of the child's necessary dependence on its external authorities because of its ineffectual superego. What she implies here is that the analyst's clinical project is to aid the child in the introjection of a superego by, in fact, becoming the child's ego-ideal - the child's ideal authority. This is, as she once wrote, an indispensible 'period of preparation - a period of “breaking the child in" for analysis...' (A. Freud, 1926, p. 7). For Anna Freud, the child analyst ought to buttress the parents' authoritative position, using love and affection to encourage the child to develop socially acceptable sublimations and repressions. In contrast to her father who theorized the superego - the psychic representative of social authority - as a precipitate of anxiety and guilt, Anna Freud here implicitly posits the possibility of a less conflicted superego, one founded on un-ambivalent love and presence rather than anxiety and loss. 'The really fruitful work,' she summarizes, 'always takes place in positive attachment' (A. Freud, 1926, p. 41). ${ }^{14}$

\footnotetext{
${ }^{14}$ Although never a terribly popular analyst in London - she became well known as a 'difficult' person and was described by Ernest Jones in a letter to Melanie Klein in 1942 as a 'tough and indigestible morsel' - Anna Freud's uncompromising advocacy of the child's positive transference garnered special criticism (Young-Bruehl, 2008, 259). Her position was attacked for a wide range of reasons: her adversaries contested everything from the 'unpsychoanalytic' nature of her technique to the 'unanalyzed' aspects of her own person in order to dismiss her theory. She would eventually come to revise this emphasis on a necessarily positive transference, claiming in the 1970s and 1980s that her early work had
} 
To elaborate this postulate about the positive transference, Anna Freud narrates the case of a ten-year-old boy in which she actively curates the boy's dependence, using her own authority to secure his attachment to her. This boy, who presented clinically with 'an obscure mixture of many anxieties, nervous states, insincerities, and infantile perverse habits,' distrusted Anna Freud from the outset and refused to disclose his 'sexual secrets' (A. Freud, 1926, p. 11). In answer to this suspicion, she embarks on a subtle process of one-upmanship, matching each of the boy's actions and behaviors with superior versions of her own:

If he came with a string in his pocket, and began to show me remarkable knots and tricks, I would let him see that I could make more complicated knots and do more remarkable tricks. If he made faces, I pulled better ones; if he challenged me to trials of strength, I showed myself incomparably stronger. (A. Freud, 1926, p. 12)

Anna Freud's aim in performing this repertoire of herculean feats is to make herself 'useful' to the boy precisely by establishing herself as an authority on the subjects in which he is interested. She endeavors to show herself 'incomparably stronger' so as to gain his trust, bringing him to rely on her as an authority capable of shielding him from punishment and mitigating his destructive onslaughts. Anna Freud continues:

Besides an interesting and useful companion I had become a very powerful person, without whose help he could no longer get along. [...] I had made myself indispensable to him and he had become dependent on me. But I had only waited for this moment to demand of him in return the most extensive cooperation, though not in words and not all at one stroke: I asked for the surrender, so necessary for analysis, of all his previously guarded secrets... (A. Freud, 1926, pp. 13-14)

By encouraging the boy's positive attachment and dependence, Anna Freud had in effect become an authority without whom he could no longer make do. Love and authority here work

unduly privileged the child's affectionate (rather than hostile) feelings. However, even with this latecoming codicil, the cultivation of a positive transference is still a hallmark of Anna Freud's overall technique. For an example of this revised position, see the 'Introduction' to Volume I of The Writings of Anna Freud (1926, pp. vii-xii). 
together to produce the conditions that she believes to be the necessary groundwork for any further analytic work. '[T] he child analyst, who in any case is bigger and older than his little patient $[\ldots]$ becomes a person of unquestioned power when the child feels that his authority is accepted by the parents even above their own' (A. Freud, 1926, pp. 22-23). What this positive transference to an analytic authority yields, according to Anna Freud's terms, is yet another layer of the hierarchal relation: if all goes as planned, the child is then willing to 'surrender' to the analysis, giving over 'all his previously guarded secrets' as the final coup-de-grace to the analyst's authority.

While a positive transference is the first key modification that Anna Freud suggests for child analysis, the second - already suggested by the above case study - is that the analyst be a pedagogical authority for the child-patient. Anna Freud imagines the child analyst's function to be quite different from the passive 'mirror' that Sigmund Freud had proposed for analysts working with adults. 'The child analyst must be anything but a shadow,' she cautions (A. Freud, 1926, p. 45). ${ }^{15}$ According to her advice, analysts should not simply act as passive reflectors of unconscious material since the young child suffers not from reminiscences, but from current events. Given the fact that the child is actively negotiating the often-conflicted process of turning an external authority into an internal structure, Anna Freud avers that the analyst ought to provide 'support' throughout this process, helping the child to construct stable psychic structures

\footnotetext{
${ }^{15}$ Anna Freud's reference to the analyst as 'shadow' calls to mind Sigmund Freud's use of the same term in 'Mourning and Melancholia' (1917). In describing the psychic effects of loss for the melancholic, Sigmund Freud writes enigmatically that the 'shadow of the object fell upon the ego' leaving its trace upon the ego's structure. While shadows, like mirrors, are in some sense doubles - they are a derivative outline of a primary, 'authentic' object - they differently connote concepts of light and obstruction. Whereas mirrors are the surface onto which reflections of the object are cast, representing the object in ostensibly perfect detail, shadows are the result of the object's obstruction of light. They are the 'dark side,' so to speak, produced by an object's embodied placement in relation to a light source. Rather than a doubled presence, they index an absence. Anna Freud's use of this term thus already speaks to how she understands the child analyst in terms of presence and absence rather than doubled reflection.
} 
through the authority of her presence, rather than prompting them to deconstruct solidified ones through transference and interpretation. Like a teacher or parent, the child analyst must mete out freedom with due discipline.

To give another brief example of the authority she promotes in the analyst, Anna Freud explains her analytic technique in 'Child Analysis and the Upbringing of Children' by recounting her clinical work with a six-year-old girl who was brought to analysis because of an obsessional neurosis, which resulted in an overly inhibited demeanor. ${ }^{16}$ Anna Freud interprets this inhibition as indicating a repression of the girl's hostile and sadistic feelings against her mother, which the girl had split off into another part of her personality, calling this her 'devil.' By initially allowing the child to express these feelings without censure in the clinic, Anna Freud 'brought [her] young obsessional patient to the point of allowing her 'devil' to speak,' a change that transformed not only the way the child behaved in the analytic hour, but also her personality at home (A. Freud, 1926, p. 61). However, the tentative license that Anna Freud gave her young patient did not at all go as she had planned. Having lifted the girl's external prohibitions and restrictions, she summarizes the results:

In the absence of external condemnation, the child lost all moderation, carried over into her home all the ideas previously expressed only during analysis, and

\footnotetext{
${ }^{16}$ Although I do not have the space to discuss it at length here, another interesting instance of the place of authority in Anna Freud's clinic can be found in her first psychoanalytic paper, 'Beating Fantasies and Daydreams' (1922). In that paper, Anna Freud discusses an adolescent girl who is plagued by what she calls her 'nice stories,' that is pre-modern narratives about a sinister knight and his capture and confinement of a male youth. Tracing the evolution of these political parables from earlier beating fantasies between teachers and boys, Anna Freud repeatedly emphasizes that what the two scenes share is an 'antagonism between a strong and a weak person' (148). In other words, both scenes traffic in the dissemination of (patriarchal) authority from adults to children. This co-incidence of authority in the clinic is then only compounded by the fact that, as most scholars recognize, the young girl in question that anonymous 'patient' who found sexual satisfaction in the paternal subjection of children to pedagogical discipline - is none other than the progenitor of a clinical technique of child analysis that promotes the generational exercise of pedagogical authority as its most defining feature. If the knight in Anna Freud's eroticized daydream intends to torture the youth for his guarded secrets, then what are readers to make of Anna Freud's clinical desire to use her own authority to extract sexual secrets from her own child-patients?
} 
completely reveled, as she had with me, in her anal preoccupations, comparisons, and expressions... My little patient had behaved like a pervert or a mentally ill adult, and thereby put herself beyond the pale of society. Since she was not removed from the company of others, they removed themselves from her. During this period she abandoned all restraints in other respects as well. In a few days she had become transformed into a cheerful, insolent, and disobedient child, by no means dissatisfied with herself. (A. Freud, 1926, p. 62)

Using morally weighted language, Anna Freud reflects that she "had changed an inhibited, obsessional child into one whose "perverse" tendencies were liberated,' casting her 'beyond the pale of society' (1926, 63). The way Anna Freud interprets the little girl's abandonment of all social decorum is used as proof that children do not possess stable, self-regulating superegos and thus require the exercise of external authority if they are going to become other than a Hobbesian subject in the state of nature. For Anna Freud, this was a revelatory moment in the development of her analytic technique and it solidified her conviction that children need not only to be treated by different methods than adults, but that authority in particular is a critical element for any successful child analysis:

I had to acknowledge that I had made a mistake, in crediting the child's superego with an independent inhibitory strength which it did not possess. As soon as the important people in the external world had relaxed their demands, the child's superego, previously strict and strong enough to bring forth a whole series of obsessional symptoms, suddenly turned compliant... I had changed an inhibited, obsessional girl into one whose 'perverse' tendencies were liberated. But, in doing so, I had also ruined the situation for my work. This liberated child now had her 'rest hour' all day long, lost her enthusiasm for our joint work to a considerable degree... (A. Freud, 1926, p. 63)

As a corrective to what she considered this early misstep in the analysis, Anna Freud subsequently assumes a much more authoritative relation to the child and reinstates many of the original expressive prohibitions, especially those that related to the child's behavior outside of the clinic. Notes Anna Freud: 'I fulfilled her apparent desire to have authoritative demands imposed on her' (A. Freud ,1926, p. 19). Anna Freud justifies her superegoic, authoritative 
intervention by (re)turning to an explicitly pedagogical idiom, emphasizing the importance of analytic 'guid[ance]' and children's 'learn[ing].' She opines further, in the same lecture:

The analyst must claim for himself the liberty to guide the child at this important point, in order to secure, to some extent, the achievements of analysis. Under his influence the child must learn how to deal with his instinctual life; the analyst's views must in the end determine what part of the infantile sexual impulses must be suppressed or rejected as unsuitable in civilized society... (A. Freud, 1926, p. 60)

Here, it is the analyst's job to 'civilize' the (presumably 'savage') child, taking what liberties she must in order to 'guide' and 'influence' the child toward the proper sublimations. Placing the analyst's authority on the side of civilization, Anna Freud likens the child analyst to a teacher or leader, whose ability to produce civil society is conditional on their authoritative suppression of unruly masses. Anna Freud thus uses this case, which itself raises the question of the analyst's potentially pedagogical and disciplinary function, as a pedagogical object lesson for the reader, showcasing the moral failures of an undisciplined heroine - both the child given too free a rein, and herself as an initially too-lenient analyst.

This case occupies an important place within Anna Freud's early lectures since, through it, she justifies the implementation of the preparatory period in child analysis, which she (as much as her many critics) acknowledges to be thoroughly unanalytic. She returns to the case frequently throughout her writings and uses it to argue that such pedagogical measures are not just necessary in this one particular case, but are also a vital component in all child analyses. As Anna Freud continually makes explicit, because of the undeveloped nature of the child's mind it is incumbent on the child analyst to be simultaneously psychoanalytic and pedagogical; the child analyst must negotiate an unwieldy balance between the exercise of authority and its critique. As she states a few pages later in the same lecture, 
I would not have enlarged upon this example if it did not serve to illustrate all the characteristics of the analysis of children put forward in this last section: the fact that a child's superego is weak; that his superego demands and consequently his neurosis are dependent upon the external world; that the child himself is incapable of controlling the instincts that have been freed; and that for this reason the analyst must take charge and guide them. The analyst accordingly combines in his own person two difficult and diametrically opposed functions: he has to analyze and educate, that is to say, in the same breath he must allow and forbid, loosen and bind again. If the analyst does not succeed in this, analysis may become the child's charter for all the ill conduct prohibited in society. (A. Freud, 1926 , p. 65, emphasis added)

Avowing the oppositional nature of these two pursuits - education and psychoanalysis - Anna

Freud nevertheless frames the technical uniqueness of child psychoanalysis as its almost impossible combination of them. The child's willingness and ability to conform to social expectations (primarily those having to do with sexuality and aggression) is a key part of how Anna Freud narrates the 'normal development' - that is, the 'healthy development' - of the child, whose instinctual self-satisfactions must be tempered by cultural restrictions that are imposed as much by the authority of the analyst as by that of the forbidding teacher. In the pedagogical exercise of authority, the analyst, like the teacher, is a 'real' person for the child, an external authority on which the child's superego can lean as a crutch: '[t]he educational implications which, as you will hear, are involved in the analysis, result in the child knowing very well just what seems desirable or undesirable to the analyst, and what he sanctions or disapproves of' $(1926,46)$. In this way, Anna Freud puts this case to work to prove the exceptional and unorthodox authority that the child analyst must assume with children in order to avoid the collapse of culture altogether.

Although this appreciation of authority has much in common with Sigmund Freud's Group Psychology and the Analysis of the Ego and his later Civilization and Its Discontents, it is important to recall that Anna Freud (unlike her father) advanced this ethics of authority, 
guidance, and external support specifically in relation to the child in the clinic. While Sigmund

Freud, in Group Psychology, described the social organization of groups and leaders through his theory of identification, which he argues is the means by which the child introjects his father as his first authority, Anna Freud adopted this social hypothesis as her clinical premise, prescribing it to the children she analyzed. In a letter to family friend Max Eitingon the same year that she delivered these lectures (1926), Anna Freud confessed her personal attachment to her father's Group Psychology, telling Eitingon: ‘ ...everything was in there, my old daydreams and all I wanted.' Group Psychology functioned for Anna Freud as the authoritative text about authority. Her project, as she articulates it, is not one of speculative social theorization but of clinical construction and creation. Anna Freud therefore took her father's political theory with its emphasis on the need for social authority and suggested that the subjects most in need of this particular kind of governance were children in analysis. ${ }^{17}$ In her own terms, Anna Freud argues that the child analyst's function ought to be the (necessarily prescriptive) production of subjectivity through the careful orchestration of authority:

We may say in short: the analyst must succeed in putting himself in the place of the child's ego ideal for that duration of the analysis; he ought not to begin his analytic work of liberation until he has made sure that the child is eager to follow his lead. For this purpose, it is essential that the analyst have the position of authority about which we spoke at the beginning. Before the child can give the highest place in his emotional life, that of the ego ideal, to this new love objects

\footnotetext{
${ }^{17}$ Read from a wider historical angle, Group Psychology is a rather politically over-determined text. Ironically, while Anna Freud's clinical method borrowed from this text, so too, according to Mark Edmundson, may have an up-and-coming Adolf Hitler. Edmundson (2007) records that 'Hitler's biographer, John Toland, speculates that Hitler may have read Group Psychology and used it to guide his [political] performances' and public speeches (Edmundson, 2007, p. 56). Whether or not we take this historical conjecture as an accurate representation of Hitler's literary habits is hardly the point since Toland's inclination to even speculate on this possibility registers the text's strong conceptual resonance with the dynamics of political authority, in this case, authoritarianism. This, at the same time as socialist radical Wilhelm Reich used Freud's writing on mass psychology as the premise for The Mass Psychology of Fascism (1933). Unlike Reich, Anna Freud did not mobilize the premises offered in Group Psychology for a social diagnosis, but adopted them as the prescripts for her own professional undertaking, imagining her version of democratic subjectivity on and through the reproduction of (patriarchal) authority.
} 
which ranks with the parents, he needs to feel that analyst's authority is even greater than theirs. (A. Freud, 1926, p. 60; emphasis added)

Knowing how the psychic life of an adult ought to be structured in order to minimize suffering, Anna Freud propounds a technique that seeks to lead children toward specific ends. To this end, Anna Freud maintains that psychoanalysis - and psychoanalysts - ought to encourage children to as much as possible bring their instinctual needs under the guiding authority of the ego and superego; the analyst's work is about using her or his authority to transform socially unacceptable instinctual urges into what she or he understands to be socially useful and gratifiable ones, thereby reproducing stable, 'civilized' society. Anna Freud said as much in the late decades of her career, after the human and material destructions of World War II, in the lecture series she gave in Boston for Harvard and Radcliffe students. In a talk titled 'The Unconscious' (1952), she advised that 'to change the environment of the child so that it fits the nature of the child... is all wrong. It does not work out well for the child, and for the adult community it means a loss in cultural values. It is the child who should go forward into the community' (Sandler, p. 6). According to Anna Freud, radical social transformation was not the purview of psychoanalysis. ${ }^{18}$ The particular forms of government, and the political relations contained therein, that Anna Freud was able to imagine were delimited by the consolidated norms of culture and community. Anna Freud's theories about clinical technique suggest the

\footnotetext{
${ }^{18}$ While Anna Freud did seek, throughout her postwar career, to accommodate displaced children, these group homes were never organized with the conscious intention of transforming family structures; rather, they sought to reduce, as much as possible, the changes forced by the exigencies of total war and the damage wrought by genocidal National Socialism. Their project was compensatory far more than it was progressive; Anna Freud sought stability, not revolution. Indeed, these homes very often tried to reproduce internally the same conditions of liberal (heteronormative) family life as Anna Freud imagined the child would have experienced in her own family by creating institutional 'mothers' and 'fathers' and Anna Freud frequently went out of her way to ensure biologically male authorities were present. For further reading, See A. Freud, 1973, especially 'Introduction of the Mother Relationship Into Nursery Life' and 'The Role of the Father in the Residential Nursery' in Part II.
} 
productive significance of the wider, socio-political order for the organization of individual psychic life insomuch as the socio-political order both provides the conceptual idioms through which analysts theorize subjectivity and insomuch as it sets the perimeters of the social world to which the patient will be asked to conform.

\section{Follow the Leader: On Authority and Democracy}

In the psychoanalytic consulting room, child analysts like Anna Freud were actively (re)creating and implementing revised clinical techniques to manage the child-subject, as they understood it. These techniques, and indeed the very narratives they used to define 'the child' as a particular kind of subjectivity, often pulled from the explicitly political vocabularies available to them. Terms like 'authority,' 'liberation,' 'leadership,' 'attack,' 'defense,' 'tyranny,' and 'reparation' (to mention but a few) were a regular part of the rhetoric analysts used to theorize

the child-subject's metapsychology and legitimate a clinical technique. Take, for instance, Anna Freud's brief description of the ego from her landmark 1936 The Ego and the Mechanisms of Defense in which she mobilizes politicized rhetoric to elaborate psychic structures:

the proper field for observation is always the ego. It is, so to speak, the medium through which we try to get a picture of the other two institutions. When the relations between the two neighboring powers - ego and id - are peaceful, the former fulfills to admiration its role of observing the latter. (A. Freud, 1936, p. 6)

Using language that registers the regulatory, institutional social structures that were the condition of possibility for Anna Freud's conception of the ego, readers might also note the clearly political idioms informing her conception of the (international) 'relations' between these 'neighboring powers.' Poised on the brink of World War II, Anna Freud argues in 1936 that the goal of analysis is negotiating 'peace' between these conflicted institutions, the ego and the id, whose personification as nation-states begs the question of their respective political signification. 
The geopolitical underpinnings of this metapsychology are far from novel, though, given that Sigmund Freud had been marshaling war imagery in his psychoanalytic papers from the very start. ${ }^{19}$ Indeed, the fact that Anna Freud's most enduring clinical legacy has been an unrelenting focus on the analysis of ego 'defenses' already speaks to a lifetime spent caught between two world wars, a career embroiled in a major intra-institutional struggle for political power, and a subjectivity entrenched in racialized and gendered limitations. Psychoanalysts, as much as many other human scientists, were developing their conception of the child subject in the midst of a larger political discourse that was, newly, thinking about government and (inter)national conflict on global scales.

As I have been arguing, what is interesting about Anna Freud's early work is the extent to which the clinical technique she develops turns to the operation of authority as the solution for the problems introduced by the 'undeveloped' and 'immature' child-mind. For the child, unlike the adult, the liberatory potential of psychoanalysis is to be found precisely in the judicious embodiment and exercise of authority. This treatment of authority represented a significant break with the thought of her various socialist colleagues who, largely, wanted to de-emphasize the censures of the superego, since this rigid and repressive internal authority was understood to be the root of much unnecessary psychical conflict. As the sweeping political appeal of authoritarianism was made more and more evident throughout the 1930s and 1940s, thinkers like Marcuse, Fromm, and Adorno grew increasingly wary of the psychic effects of authority and, as a tactical response to this zealotry, they theorized authoritarianism as the political correlate of the psychic introjection of authority. Citing Fromm specifically, Frank Furedi observes in his comprehensive survey of social theories of authority that there was an increasing tendency

\footnotetext{
${ }^{19}$ For a reading of the political dimensions of Freud's deployment of war metaphors and imagery, see Brunner (2001).
} 
(throughout the interwar period, but during the rise of European fascism, especially) 'to lose sight of the distinction between authority and power, and between terms like "authority" and "authoritarian"” $(2013,362)$. In many interwar social and political discourses, authority and authoritarianism became synonymous; an emphasis on the former translated into a natural affinity for the latter. As the threat of multiple authoritarian regimes mounted in the 1930s, psychoanalytic rubrics that detailed the individual internalization of authority became powerful narratives for diagnosing the appeal of authoritarianism as a form of governance and for strategizing different kinds of social eugenics to stymie its recurrence. ${ }^{20}$

In contrast to these thinkers, who equated authority with authoritarianism and sought to retrench the hold of the superego as the internal representative of oppressive political authority, Anna Freud interestingly propounded a clinical technique in which children's 'liberation' (as she put it) was contingent on the successful internalization of precisely this internal authority - the superego. By combining pedagogical with psychoanalytic methods in the clinic, Anna Freud argues emphatically for the necessity of restrictive authority in the upbringing - and analysis - of the child. When it comes to the child in the clinic, freedom paradoxically comes from obedience, authority, and analytic leadership. As Midgley confirms, '[i]n contrast to the dominant view of psychoanalysis at the time, which many people understood to be promoting unfettered freedom of expression, Freud emphasized that "lack of restraint" can be as harmful to children as "the injurious effect of too great repression"' (2013, p. 48). Put simply, Anna Freud's primary

\footnotetext{
${ }^{20}$ Although D.W. Winnicott is not particularly concerned with authority, on the topic of social eugenics we might think here of the many postwar BBC public broadcasts that he gave in which he counseled mothers on the best techniques for infant management, making explicit that successful childcare was the unequivocal foundation for a democratic polis. For an example of this tendency in Winnicott's work, see 'The Mother's Contribution to Society' in Home Is Where We Start From (1990). For critical analyses of the historical and political implications of Winnicott's postwar work, see Riley (1983); Gerson (2005) and (2004); and Alexander (2013) and (2016).
} 
concern in these early papers was not with mitigating the injurious effects of too strong an authority, but with curtailing those begat by too great a freedom.

Yet Anna Freud was not alone in her conceptual turn to authority as a strategic solution for the problems incurred by excessive ungoverned liberty. While socialist anti-authoritarians on the cusp of World War II were highly critical of authority, emblazing it as the antithesis of (democratic) freedom, there was a large sect of European interwar intellectuals who were wary of democratic tenets and embraced instead a concept of authority as a potential solution to the problems inherent in pure democracies. After World War I ended and the Austro-Hungarian Empire was dismantled and partitioned into smaller, ethnic nation-states, the newly minted Austria struggled to articulate the legitimacy of its constitutional foundations (Caldwell, 1997, p. 92). In the abrupt transition from monarchial empire to democratic republic, many (both leftists and conservatives) were ambivalent about not only the republic's legitimacy, but also about its desirability. When it came to Austria specifically, all three of the largest political parties at the time - The Christian Social Party The Social Democrats, and the Greater German Nationals had doubts about a liberal Austrian democracy: the conservative Christian Social Party would have preferred a traditionalist return to monarchy; the Social Democrats were amenable to democracy, but lobbied for a more fully socialist economy; and the German Nationals avidly vied for official unification with Germany (Jelavich, 1987, p. 170). ${ }^{21}$ Popular sentiment in

\footnotetext{
${ }^{21}$ Although interwar Austria's political parties are typically described in this three 'camp' (Lager) model, this partitioning can misrepresent some of the major similarities across the different parties (Wasserman, 2014, 8-9). For instance, the majority of Austrians across the political spectrum (not just German Nationals) strongly desired an Anschluss with Germany. Moreover, while Christian Socials were vocal in their anti-democratic claims for an ethnically unified, traditionalist state, they were far from the only ones to nostalgically lament the loss of the monarchy. Indeed, many artists, intellectuals, and leftists likewise longed for the monarchy after its abrupt decline. Such a desire was hardly a badge of conservatism since, as the minoritized Jewish population especially realized, many liberal social and political protections had been more securely guaranteed under Franz Joseph's progressive rule than under that of nascent
} 
Austria prior to World War II was thus more than a little skeptical of democratic republicanism, with a majority of the population expressing open hostility about the Allies' ideological project of enforced democratization. For many interwar Austrians and Germans, the imperative to build democracy had the strong smell of cultural imperialism and its premises of majority rule often appeared as a threat rather than a promise. As Furedi speculates, it has perhaps only been retrospectively, after the disastrous effects of the twin authoritarian regimes of Stalinism and National Socialism, that democracy has come to be so idealized, enshrined as a broadly uncontested ethico-political virtue (2013, p. 351). However, prior to the psychic and material violence of genocidal fascist and socialist regimes, democracy was treated with much more ambivalence, in large part because its relationship to authority was ambiguous. ${ }^{22}$

Harkening back to the crowd psychologists of decades before, this negative suspicion about the lack of legitimate, regulatory authority in democratic governments frequently took the form of a widespread anxiety about the irrational nature of 'public opinion' and the deficiencies of the ungoverned 'masses.' Conservative political commentators distrusted the sound decision making of the public majority, likening them to 'children' and 'primitives' in a developmental framework reminiscent of Sigmund Freud's anthropological epic, Totem and Taboo (1914). Writes American commentator Walter Lippmann in his 1922 critique of democracy, Public Opinion:

democracy. For an analysis of the representation of the Habsburg monarchy after its decline, see Kożuchowski (2013).

${ }^{22}$ In an interesting twist to the skepticism about democracy, the rise of authoritarian governments throughout Europe was then cited as an additional proof of democracy's failures. Hungarian sociologist Karl Mannheim elaborated this position in 1933 when he wrote in 'The Democratization of Culture' that '[d]ictatorships can only arise in democracies... Dictatorship is not the antithesis of democracy; it represents one of the possible ways in which a democratic society may try to resolve its problems' (Cited in Furedi, 2013, p. 353). 
The mass of absolutely illiterate, of feeble-minded, grossly neurotic, undernourished and frustrated individuals, is very considerable, much more considerable there is reason to think than we generally suppose. Thus a wide popular appeal is circulated among persons who are mentally children or barbarians, people whose lives are a morass of entanglements, people whose vitality is exhausted, shut-in people, and people whose experience has comprehended no factor in the problem under discussion. (Lippmann, 1922, p. 68)

Lippmann here interestingly compares the psychological sophistication of the masses, whom he imagines are politically untrustworthy because of their susceptibility to uninformed public opinion, with children and 'barbarians,' categories of subjectivity that he (like Anna Freud) implicitly assumes are in need of authoritative guidance. For Lippmann, authority was far from a threat to democracy; rather, it was democracy's solution, the necessary supplement to a system internally flawed.

In a similar fashion, albeit from a much more progressive angle, Max Weber's interest in charismatic authority as an antidote to the deadening effects of routinized bureaucracy expresses a similar reinvestment in the political purchase of authority. Working against the hegemonic ascent of modernity, with its values of rationalism, secularism, capitalism, and professionalism a historical movement Weber felicitously called 'disenchantment' - Weber (re)turned to a theory of charismatic authority. Although Weber did not argue for the appeal of authority in these terms, this interest in the importance of a 'natural' leader capable of bestowing order and unity speaks to an anxiety about the tenability of mass democracy. While Weber argued for the democratization of Germany during the war and after its resolution, he importantly understood democracy in terms of leadership, with an unvarnished emphasis on the extent to which the condition of possibility of any political state is force, violence, and domination. As Weber observes with a bleak realism in 1919: 'the state is a relation of men dominating men, a relation supported by means of legitimate (i.e. considered to be legitimate) violence. If the state is to 
exist, the dominated must obey the authority claimed by the powers that be' (1946, p. 78). For Weber, the complementary element of any constitutional democracy was a charismatic authority, a leader whose qualified authority ensured the productive curtailment of majority rule. Only through the dissemination of charismatic authority could a true 'leadership democracy' be established. Thus, during World War I and the interwar years, Weber (and others) looked increasingly to political fantasies of the ascension of authority and the constructive recombination of authority and democracy as a potential solution to the problems raised by majority rule and the uncertain legitimacy of the new constitution during the abrupt transition from empire to democratic republic. ${ }^{23}$

Certainly, Anna Freud never consciously or explicitly endorsed these political views and none of these critics were ever centrally involved in the inner circles of psychoanalytic practice and theorizing. My point here is not to suggest otherwise. However, I do want to mark out a certain rhetorical similarity between interwar critiques of democracy that promoted authority as a necessary supplement - or out-and-out solution - to democracy and Anna Freud's interwar theories of child technique, which anxiously testified to the indispensability of analytic authority for governing the child's unruly instincts. The contested place that authority occupied in debates about democracy in the interwar period helps contextualize the complex political signification of authority in Anna Freud's clinic. Understood in this context, we can read Anna Freud's focus on authority not as a rejection of democracy, but rather as indexing an anxious struggle about the

\footnotetext{
${ }^{23}$ For an interesting additional example of this discourse about democracy in Austria, specifically, Richard von Kralik, the conservative historian, author, and intellectual, hailed what he called a 'true democracy.' 'True democracy... comprises the whole people and all its social groups [Ständen] with the monarch as the head of the social body... All true culture is Volkskultur' (qtd in Wasserman, 2014). Part authoritarian, part monarchist, part Germanic anti-Semite, Kralik was one of the leading intellectuals in Vienna during the interwar period, a station made clear by the number and intensity of reproofs that Karl Kraus directed at his work. He, as much as Weber, sought to redefine democracy through the implementation of a stronger central authority.
} 
relationship between political authority and democracy itself. A turn toward authority carries with it a critique of the inadequacies of liberal democracy, yes, but it is also intended as a supplemental solution to that problem rather than rejection of it. As Anna Freud imagines it, the analyst's job - much like a Periclean figure - is to impose a hierarchal authority as, paradoxically, the best means for constructing democratic civil society. In this interwar work, authority interestingly becomes the solution to - rather than antagonist of - the lack of order and guidance characteristic of democracies. Thus, while it is my contention that Anna Freud's vocabulary of clinical leadership and authority speaks to a thoroughly political discourse underwriting Anna Freud's clinical project, I mean this argument to suggest a complication of her relation to democracy, one that was a keynote in the interwar anxieties about the rapidly transforming forms of government in Europe. If Anna Freud's interwar clinical techniques meditated on 'good' authority, then this was as a supplement to, rather than a wholesale dismissal of, the uncertain political futures of democracy. 


\section{References}

Aichhorn, A. (1965) Wayward Youth. New York: Penguin.

Aires, P. (1965) Centuries of Childhood: A Social History of Family Life. New York: Vintage.

Alexander, S. (2012) Primary maternal preoccupation: D.W. Winnicott and social democracy in mid-twentieth-century Britain. In History and Psyche: Culture, Psychoanalysis, and the Past. New York: Palgrave Macmillan.

Alexander, S. (2016) Winnicott and the social democratic vision. In M. ffytche and D. Pick (eds) Psychoanalysis and the Age of Totalitarianism. London: Routledge, 2016.

Bar-Haim, S. (2017) The child's position: The concept of childhood in interwar psychoanalysis. Fragile Subjects: Child Figures in Western Modernity. London: Routledge.

Britzman, D. (2003) After-Education: Anna Freud, Melanie Klein, and Psychoanalytic Histories of Learning. New York: New York State UP.

Brunner, J. (2001) Freud and the Politics of Psychoanalysis. London: Routledge.

Caldwell, P.C. (1997) Popular Sovereignty and the Crisis of German Constitutional Law: The Theory and Practice of Weimar Constitutionalism. Durham: Duke University Press.

Castañeda, C. (2002) Figurations: Child, Bodies, Worlds. Durham: Duke University Press.

Coles, R. (1992) Anna Freud. Reading, MA: Addison-Wesley Publishing Co.

Cunningham, H. (1995) Children and Childhood in Western Society since 1500. New York: Longman.

Danto, E. (2005) Freud's Free Clinics: Psychoanalysis and Social Justice, 1918-1938. New York: Columbia University Press.

Edmundson, M. (2007) The Death of Sigmund Freud: The Legacy of His Last Days. Bloomsbury Press.

Furedi, F. (2013) Authority: A Sociological History. Cambridge: Cambridge University Press.

Freud, A. Four Lectures on Child Analysis (1926). The Writings of Anna Freud, Vol I. New York: International Universities Press, 1974. 3-72.

- 'The Relation Between Psychoanalysis and Education,' Four Lectures on Psychoanalysis for Teachers and Parents (1930). The Writings of Anna Freud, Vol I. New York: International Universities Press, 1974. 121-136. 
- 'On Beating Fantasies and Daydreams,' The Writings of Anna Freud, Vol I. New York: International Universities Press, 1974. 137-157.

- The Ego and the Mechanisms of Defense (1935). The Writings of Anna Freud, Vol II. New York: International Universities Press, 1966.

- Infants Without Families: Reports on the Hampstead Nurseries, 1939-1945. The Writings of Anna Freud, Vol III. New York: International Universities Press, 1973.

- 'Child Analysis as a Subspecialty' (1970), The Writings of Anna Freud, Vol VII. New York: International Universities Press, 1971. 204-222.

Freud, Sigmund. The Standard Edition of Complete Psychological Works of Sigmund Freud: 'Mourning and Melancholia'. Trans. James Strachey. Vol. XV. New York, New York: W.W. Norton \& Co. Ltd, 1989.

- The Standard Edition of Complete Psychological Works of Sigmund Freud: Group Psychology and the Analysis of the Ego. Trans. James Strachey. Vol. XVIII. New York, New York: W.W. Norton \& Co. Ltd, 1989.

— 'Forward,' Wayward Youth. New York: Penguin, 1965.

Geissmann, C. and P. (2005) A History of Child Psychoanalysis. London: Routledge. 1998.

Gerson, G. (2004) Winnicott, participation, and gender. Feminism \& Psychology 14(4): 561-581.

Gerson, G. (2005) Individuality, deliberation, and welfare in Donald Winnicott. History of the Human Sciences 18(1): 107-126.

Edgecomb, R. (2000) Anna Freud: A View of Development, Disturbance and Therapeutic Techniques. London: Routledge.

Hendrick, H. (1997) Children, Childhood, and English Society 1880-1990. Cambridge: Cambridge University Press.

Holder, A. (2005) Anna Freud, Melanie Klein, and the Psychoanalysis of Children and Adolescents. London: Karnac.

Jelavich, B. (1987) Modern Austria: Empire \& Republic, 1800-1986. Cambridge: Cambridge University Press.

King, P. and Steiner, R. (eds) (1991) The Freud-Klein Controversies: 1941-45. London: Tavistock/Routledge.

Klein, M. 'The Psychological Principles of Early Analysis (1926).' Love, Guilt, and Reparation and Other Works 1921-1945. New York: The Free Press, 1975. 128-138. 
- 'Criminal Tendencies in Normal Children (1927).' Love, Guilt, and Reparation and Other Works 1921-1945. New York: The Free Press, 1975. 170-185.

- 'Symposium on Child-Analysis,' Love, Guilt, and Reparation and Other Works 19211945. New York: The Free Press, 1975. 139-169.

Kożuchowski, Adam. The Afterlife of Austria-Hungary: The Image of the Habsburg Monarchy in Interwar Europe. Pittsburgh, PA: University of Pittsburgh Press, 2013.

Midgley, Nick. Reading Anna Freud. London: Routledge, 2013.

Phillips, Adam. 'Bombs Away,' Promises, Promises: Essays on Psychoanalysis and Literature. New York: Basic Books 2001.

Reich, Wilhelm. The Mass Psychology of Fascism. New York: The Noonday Press, 1970.

Riley, Denise. The War in the Nursery: Theories of the Child and Mother. Virago Press, 1983.

Rose, Jacqueline. 'War in the Nursery.' Why War?: Psychoanalysis, Politics, and the Return to Melanie Klein. Oxford: Blackwell UP, 1993. 191-230.

Sandler, Joseph, Hansi Kennedy, and Robert L. Tyson. Techniques of Child Analysis:

Discussions with Anna Freud. Cambridge, MA: Harvard UP, 1986.

Shapira, Michal. The War Inside: Psychoanalysis, Total War, and the Making of the Democratic Self in Postwar Britain. Cambridge: Cambridge UP, 2013.

Shuttleworth, Sally. The Mind of the Child: Child Development in Literature, Science, and Medicine, 1840-1900. Oxford: Oxford University Press, 2010.

Steedman, Carolyn. Strange Dislocations: Childhood and the Idea of Human Interiority, 17801930. London: Virago, 1995.

Stewart-Steinberg, Suzanne. Impious Fidelity: Anna Freud, Psychoanalysis, and Politics. Ithaca, NY: Cornell UP, 2011.

Young-Bruehl, Elisabeth. Anna Freud. New Haven: Yale UP, 2008.

Zaretsky, Eli. Secrets of the Soul. New York: Knopf Publishing, 2004.

Wasserman, Janek. Black Vienna: The Radical Right in the Red City, 1918-1938. Ithaca: Cornell University Press, 2014.

Weber, Max. 'Politics as a Vocation.' From Max Weber: Essays in Sociology. Eds. and trans. by H.H. Gerth and C. Wright Mills. New York: Oxford University Press, 1946. 77-128. 
Winnicott, D.W. 'The Mother's Contribution to Society,' Home Is Where We Start From: Essays by a Psychoanalyst. London: W.W. Norton \& Company, 1990.

\begin{abstract}
This article provides a reading of a 'political Anna Freud' by analyzing how Anna Freud's interwar papers about the clinical technique of child analysis refracted broader political discourses about the function and effects of governmental authority. I claim that, in the interwar period, Anna Freud developed a version of child analysis explicitly interested in the authority the analyst exercised over the child-patient. By working from a developmental conception of the child, Anna Freud argued that the relatively 'undeveloped' and 'immature' nature of the child's superego made it 'dependent' on a ballast of external (analytic) authority. Anna Freud theorized this analytic authority as a corollary to pedagogical authority, a discourse that puts her in conversation with many political reformers of her time. Yet, unlike her more leftist colleagues, when it came to the clinic Anna Freud contended that authority was both practically necessary and psychically beneficial for children. As I show, this emphasis on the necessity of authority in the clinic is part of a larger, political conversation throughout interwar Europe about the status of newly minted national democracies like Austria's. While recent scholarship on Anna Freud has mined her postwar, institutional work for a latent democratic ethos, I attend to how her early, specifically clinical prioritization of authority participates in a broader interwar ambivalence about the political viability of democracy and about the ultimate need for the restoration of good authority.
\end{abstract}

Acknowledgements

My thanks go to Antonio Viego and Shaul Bar-Haim for their perceptive and encouraging readership on early versions of this article. Thanks, also, to the generous anonymous peer reviewers whose detailed feedback improved this work tremendously, and to Matt ffytche for his thoughtful and supportive editorial guidance. Finally, Renee Michelle Ragin provided scrupulous late-stage copyediting on this manuscript, for which I am very grateful. 